\title{
Intramolecular Hydrogen Bonding in 2,3-Bis-(3,4-dimethoxybenzoyl)Propionitrile
}

\author{
Francisco Sanchez-Viesca*, Martha Berros, Reina Gomez
}

Faculty of Chemistry, Graduate Division, National Autonomous University of Mexico. Mexico, D.F., 04510, Mexico

\begin{abstract}
Dimethoxybenzoylacetonitrile, required in the synthesis of some isoxazole derivatives, was obtained from $\alpha$-bromoacetoveratrone and potassium cyanide. In this reaction, a byproduct could be isolated. From its IR, ${ }^{1} \mathrm{H}-\mathrm{NMR}, \mathrm{MS}$ and elemental analysis data, it was identified as 2,3-bis-(3,4-dimethoxybenzoyl)propionitrile. A careful study of its NMR spectrum revealed the existence of two intramolecular weak hydrogen bonds, in solution in $\mathrm{CDCl}_{3}$, of the type $\mathrm{C}-\mathrm{H}---\mathrm{O}=\mathrm{C}$. Paramagnetic shifts, $\Delta \delta$, of 0.5 and $1 \mathrm{ppm}$, were found for the hydrogens involved in the interactions, as well as significant differences in the coupling constants. A molecular model confirmed the findings made by the conformational analysis. Thus, the secondary structure of the title compound was established.
\end{abstract}

Keywords Weak Hydrogen Bonds, Nuclear Magnetic Resonance, Conformational Analysis, Secondary Structure

\section{Introduction}

Following our study on intramolecular hydrogen bonding, deduced from ${ }^{1} \mathrm{H}$ Nuclear Magnetic Resonance Spectroscopy[1-3], we now present evidence for the existence of this type of atomic interactions in 2,3-bis-(3,4- dimethoxybenzoyl)propionitrile, $\underline{5}$, in solution in $\mathrm{CDCl}_{3}$. This compound was obtained as is described in the next section.

\section{Results and Discussion}

In a previous work on the synthesis of new isoxazole derivatives[4] some $\alpha$-cyano ketones were required for the syntheses. These compounds are often obtained from $\alpha$-halo ketones and an alkaline cyanide by a nucleophilic substitution. In our case, 3,4-dimethoxybenzoylacetonitrile, $\underline{1}$, and 2,4,5-trimethoxybenzoylacetonitrile, $\underline{2}$, were prepared from the phenacyl halides, $\underline{3}$ and $\underline{4}$.


$\underline{1}$
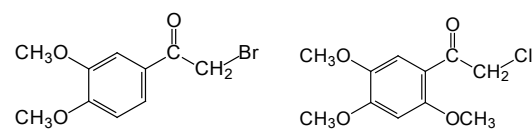

$\underline{3}$

$\underline{4}$

* Corresponding author:

franviesca@yahoo.com (Francisco Sanchez-Viesca)

Published online at http://journal.sapub.org/chemistry

Copyright (C) 2012 Scientific \& Academic Publishing. All Rights Reserved
The last two compounds were obtained by different ways. 3,4-Dimethoxyphenacyl bromide, also known as $\alpha$ - bromoacetoveratrone, $\underline{3}$, was obtained by bromination of acetoveratrone (3,4-dimethoxyacetophenone), either with bromine[5] or with cupric bromide in $\mathrm{CHCl}_{3} / \mathrm{AcOEt}$, [6].

In the last reaction, a more stable upon storage bromo ketone is obtained. This is due to the absence of elemental bromine, very reactive, as contaminant.

In order to obtain 2,4,5-trimethoxyphenacyl chloride, $\underline{4}$, a completely different method was employed. It was prepared from 1,2,4-trimethoxybenzene (a very active nucleous) and chloroacetonitrile, via a Houben-Hoesch reaction, with anhydrous $\mathrm{ZnCl}_{2}$ and $\mathrm{HCl}(\mathrm{g})$ as catalysts [7]

The next step, the $\alpha$-cyano ketones preparation, occurred in different manner with the halo-derivatives 3 and 4 . 2,4,5-Trimethoxybenzoylacetonitrile, $\underline{2}$, could be obtained after a rather long reflux heating $(5 \mathrm{hr}$ ) of chloro ketone $\underline{4}$ and $\mathrm{KCN}$ in dilute ethanol[7]. Compound 2 can also be prepared in a single step from 1,2,4-trimethoxybenzene, malononitrile and the usual catalysts of a Houben-Hoesch reaction[8]. In this reaction, cyano ketone 2 is obtained without the reddish contaminant that is formed in the KCN method.

The reaction of 3,4-dimethoxyphenacyl bromide, $\underline{3}$, with $\mathrm{KCN}$ required much less time $(20 \mathrm{~min})$ than with the chloro ketone 4. This is due to the electron donor effect of the methoxy groups at the ortho and para positions in $\alpha$-chloro-2,4,5-trimethoxyacetophenone, $\underline{4}$. This electronic effect diminishes the carbonyl reactivity, and consequently, the chlorine atom reactivity. The halogen difference must also be taken into account.

In the reaction of the phenacyl bromide $\underline{3}$ with $\mathrm{KCN}$, besides the main product, $\underline{1}$, a byproduct was formed and could be isolated by fractional crystallization. Both compounds are 
white crystalline solids. The cyano ketone 1 melts at $141-142{ }^{\circ} \mathrm{C}$ and the byproduct does it at $165-167^{\circ} \mathrm{C}$. The last compound was identified as $\underline{5}$.<smiles>COc1ccc(C(=O)CC(C#N)C(=O)c2ccc(OC)c(OC)c2)cc1OC</smiles>

\section{5}



$\underline{5 \mathrm{a}}$

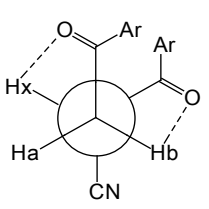

$5 b$

Its IR spectrum shows two carbonyl bands, at 1683 and $1670 \mathrm{~cm}^{-1}$, indicating the probable presence of two 3,4dimethoxybenzoyl groups. A small nitrile band at $2246 \mathrm{~cm}^{-1}$ was also found. The elemental analysis and its molecular weight (MS) are in accord with the condensed formula $\mathrm{C}_{21} \mathrm{H}_{21} \mathrm{NO}_{6}$, M.W. 383.

The ${ }^{1} \mathrm{H}$ NMR spectrum of this compound is rather complex (Figure 1). The signals were grouped in accordance with the coupling constants and the expected spin-systems. There are four methoxy signals, indicating the presence of two dimethoxy benzene rings. The existence of two carbonyl groups in the IR confirms there are two 3,4- dimethoxybenzoyl groups. Structure $\underline{5}$ contains a $\mathrm{C}_{3} \mathrm{H}_{3} \mathrm{~N}$ fragment which is in accord with the molecular weight minus two dimethoxybenzoyl groups $\left(\mathrm{C}_{21} \mathrm{H}_{21} \mathrm{NO}_{6}-\mathrm{C}_{18} \mathrm{H}_{18} \mathrm{O}_{6}=\right.$ $\left.\mathrm{C}_{3} \mathrm{H}_{3} \mathrm{~N}\right)$.

2,3-Bis-(3,4-dimethoxybenzoyl)propionitrile, $\underline{5}$, results from the reaction of cyano-ketone- 1 anion and the phenacyl bromide $\underline{3}$. Both, the aromatic hydrogens and the three aliphatic hydrogens, originate $A B X$ spin systems. The aliphatic ones present higher coupling constants: $17.7,9.0$ and $4.2 \mathrm{~Hz}$, versus $8.4,2.1$ and $1.8 \mathrm{~Hz}$ in the aromatic systems. The chemical shifts arising from the two aromatic ABX spin systems are almost coincident: they differ only by few ppm-hundredths. So, it is not possible assign chemical shifts in each ring and they are given by pairs. Even though the structure is asymmetrical, the cyano group does not exert a notorious influx on the near benzene ring because there are three sigma bonds between them.

The signals from the aliphatic protons are: $3.51 \mathrm{ppm}, \mathrm{dd}$, $\mathrm{J}_{\mathrm{ab}}=17.7$ and $\mathrm{J}_{\mathrm{ax}}=4.2 \mathrm{~Hz}\left(\mathrm{H}_{\mathrm{a}}, \mathrm{CH}_{2}\right) ; 4.06 \mathrm{ppm}, \mathrm{dd}, \mathrm{J}_{\mathrm{ab}}=17.7$ and $\mathrm{J}_{\mathrm{bx}}=9.0 \mathrm{~Hz}\left(\mathrm{H}_{\mathrm{b}}, \mathrm{CH}_{2}\right) ; 5.04 \mathrm{ppm}$, dd, $\mathrm{J}_{\mathrm{bx}}=9.0$ and $\mathrm{J}_{\mathrm{ax}}=4.2$ $\mathrm{Hz}(\mathrm{CH})$. The two aromatic $\mathrm{ABX}$ spin systems give rise to the following signals: 6.93 and $6.98 \mathrm{ppm}, \mathrm{d}, \mathrm{J}=8.4 \mathrm{~Hz}$ (H-5 and $\left.\mathrm{H}-5^{\prime}\right) ; 7.50$ and $7.56 \mathrm{ppm}, \mathrm{d}, \mathrm{J}=1.8$ and $2.1 \mathrm{~Hz}(\mathrm{H}-2$ and $\left.\mathrm{H}-2^{\prime}\right) ; 7.67$ and $7.80 \mathrm{ppm}, \mathrm{dd}, \mathrm{J}=8.4$ and $2.1 \mathrm{~Hz}, \mathrm{~J}=8.7$ and $2.1 \mathrm{~Hz}$ (H-6 and H-6').

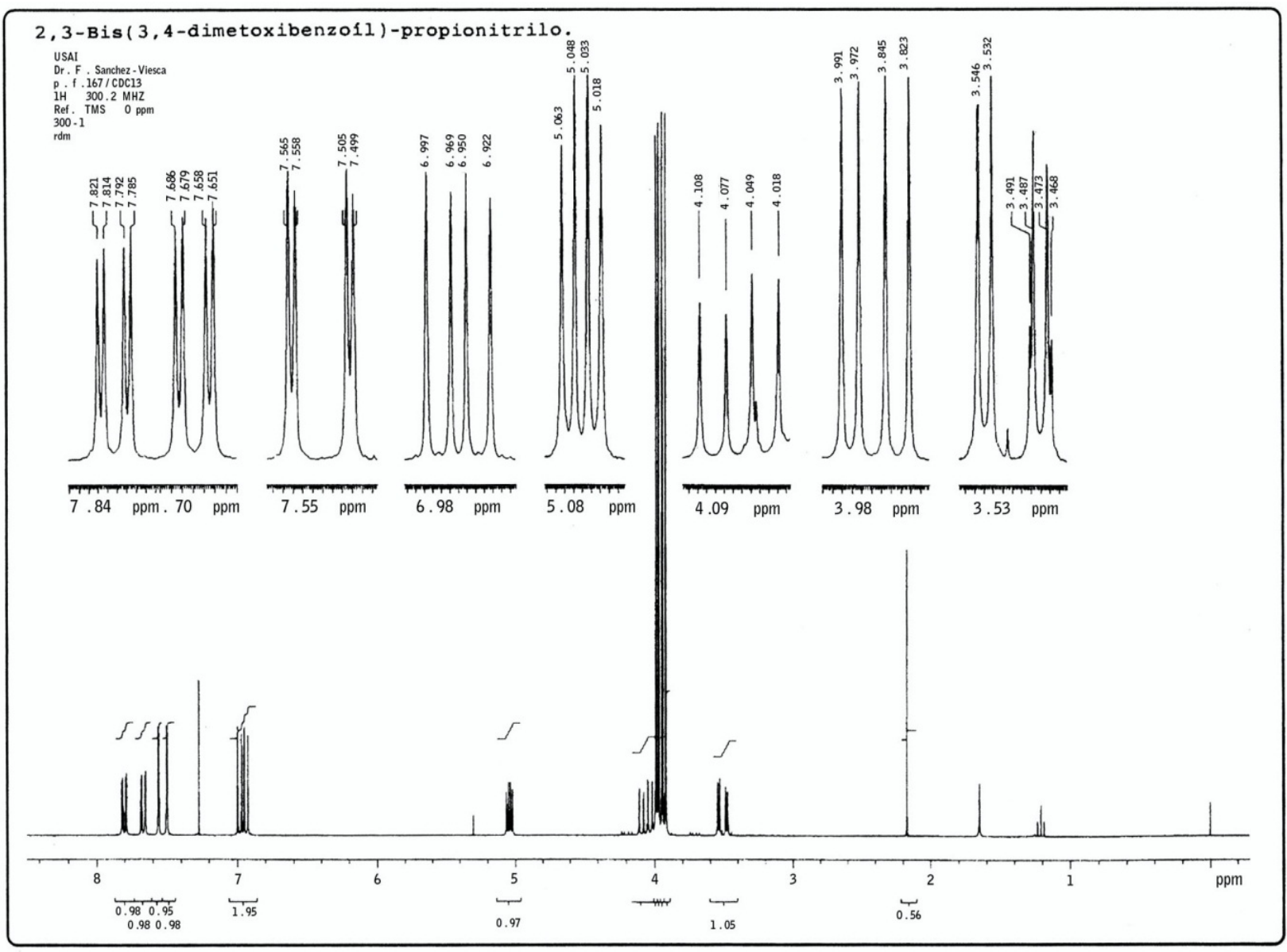

Figure 1. ${ }^{1} \mathrm{H}-\mathrm{NMR}$ spectrogram of compound $\underline{5}$ 
In cyano ketone 1 , the methylene protons, between a carbonyl and a cyano group, show a signal at $4.05 \mathrm{ppm}$. Now, in compound $\underline{5}$ the methyne proton, with similar groups, appears at $5.04 \mathrm{ppm}$, with a $\Delta \delta$ of almost $1 \mathrm{ppm}$ (only one hundredth less). This paramagnetic shift was attributed to hydrogen bond formation and this is discussed in more detail below.

In diketone $\underline{5}$, the methylene protons are magnetically nonequivalent because of restricted rotation, as it is discussed later. In this compound $\mathrm{H}_{\mathrm{b}}$ presents a $4.06 \mathrm{ppm}$ chemical shift, almost coincident with the value observed in cyano ketone 1 , and there is no cyano group linked to the methylene. Thus, this $\Delta \delta$ is attributed to hydrogen bonding. The molecular model of 2,3 - bis - (3,4 - dimethoxybenzoyl)propionitrile shows the two five-membered rings resulting from the two $\mathrm{C}=\mathrm{O}---\mathrm{H}-\mathrm{C}$ hydrogen bonds (Figure 2 ).

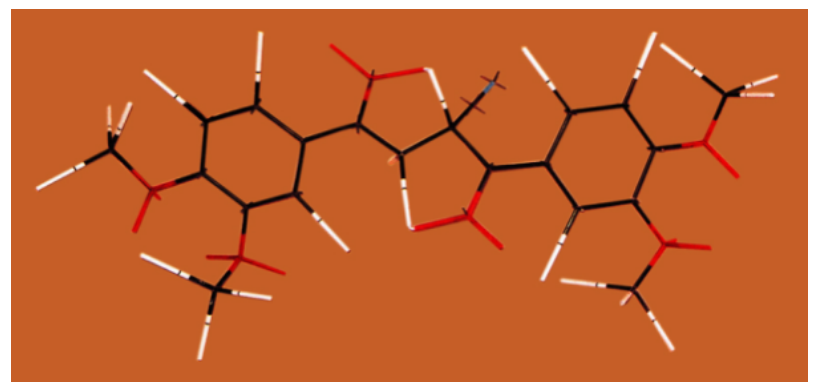

Figure 2. Molecular model of 2,3-bis-(3,4-dimethoxybenzoyl) propionitrile, 5, showing two hydrogen bonds (Framework Molecular Models, Prentice-Hall, Englewood Cliffs, N. J.)

A conformational analysis was carried out. The Newman projection $\underline{5 b}$, anti conformation, shows the $\mathrm{C}=\mathrm{O}---\mathrm{H}_{\mathrm{b}}$ and $\mathrm{C}=\mathrm{O}---\mathrm{H}_{\mathrm{x}}$ interactions. $\mathrm{H}_{\mathrm{b}}$ and $\mathrm{H}_{\mathrm{x}}$ are in antiperiplanar position, $\theta=180^{\circ},{ }^{3} \mathrm{~J}_{\mathrm{bx}}=9.0 \mathrm{~Hz} ; \mathrm{H}_{\mathrm{a}}$ and $\mathrm{H}_{\mathrm{x}}$ are in skew position, with a $60^{\circ}$ dihedral angle, ${ }^{3} \mathrm{~J}_{\mathrm{ax}}=4.2 \mathrm{~Hz}$. The geminal $\mathrm{H}_{\mathrm{a}}$ and $\mathrm{H}_{\mathrm{b}}$ have a coupling constant ${ }^{2} \mathrm{~J}_{\mathrm{ab}}=17.7 \mathrm{~Hz}$.

When a compound is not rigid, the coupling constants for vicinal protons are 5-7 Hz. In a rigid structure the coupling constants are quite different[9]. In our case, the coupling constant ${ }^{3} \mathrm{~J}_{\mathrm{bx}}=9.0 \mathrm{~Hz}$ is similar to the coupling constant (8-12 $\mathrm{Hz}$ ) for adjacent protons with axial-axial configutations in rigid systems like cyclohexane[10]. The small coupling constant, ${ }^{3} \mathrm{~J}_{\mathrm{ax}}=4.2 \mathrm{~Hz}$, is in agreement with axial-equatorial and equatorial- equatorial couplings $(3-4 \mathrm{~Hz})$ in cyclohexanes[10]. The coupling constant arising from geminal protons[11], ${ }^{2} \mathrm{~J}_{\mathrm{HH}}$, is $8-18 \mathrm{~Hz} ; 17.7 \mathrm{~Hz}$ in our case. When these protons are in a carbon atom adjacent to a carbonyl group and in a free-rotation system, the coupling constant is about $14 \mathrm{~Hz}$.

Thus, this conformational analysis proved the existence of two intramolecular hydrogen bonds in 2,3-bis-(3,4- dimethoxybenzoyl)propionitrile, $\underline{5}$.

\section{Experimental Part}

IR spectra were recorded in a Perkin-Elmer FTIR-1600 spectrophotometer, using $\mathrm{KBr}$ wafers. The ${ }^{1} \mathrm{H}-\mathrm{NMR}$ spectra
( $\delta$ downfield from internal TMS) were obtained in a Varian Inova 300 spectrometer, in $\mathrm{CDCl}_{3}$ as solvent. EI-MS data were acquired using a JEOL JMS-SX 102 A double-focusing instrument and a Finnigan Mat GCQ ion trap, with electron energy $70 \mathrm{eV}$. Elemental analysis were performed on a Fisons EA 1108 instrument.

3,4 - Dimethoxybenzoylacetonitrile, $\underline{1}$, and 2,3 - bis - (3,4 - dimethoxybenzoyl)propionitrile, $\underline{\mathbf{5}}$

$\alpha$-Bromoacetoveratrone[5,6] (1 g, 3.86 mmoles) was dissolved in boiling ethanol $(20 \mathrm{~mL})$ and a solution of $\mathrm{KCN}$ (1.5 g, 23 mmoles) in water $(6.5 \mathrm{~mL})$ was added. The solution turned yellow, was refluxed $20 \mathrm{~min}$. and the alcohol was distilled from the reaction mixture. Total heating time: $1 \mathrm{hr}$. The reaction mixture was cooled to room temperature, diluted with water $(20 \mathrm{~mL})$ and acidified (CAUTION: work in a fumehood as $\mathrm{HCN}$ is evolved) with dilute $(1: 4) \mathrm{HCl}(8 \mathrm{~mL})$. A yellow solid was obtained, filtered and washed with water. The crude product $\left(0.75 \mathrm{~g}, \mathrm{mp} 125-130^{\circ} \mathrm{C}\right)$ was dissolved in $\mathrm{CH}_{2} \mathrm{Cl}_{2}$, dried with $\mathrm{CaCl}_{2}$ and chromatographed (alumina, 7 $\mathrm{g}$ ). The product was eluted with $\mathrm{CH}_{2} \mathrm{Cl}_{2}$ and collected in 25 $\mathrm{mL}$ flasks. The light yellow fractions crystallized after evaporation to dryness (Rotavapor). $\mathrm{Et}_{2} \mathrm{O}$ was added and the solid filtered. The following fractions were obtained: $0.050 \mathrm{~g}$, $\mathrm{mp} 139-140^{\circ} \mathrm{C} ; 0.300 \mathrm{~g}, \mathrm{mp} 141-142^{\circ} \mathrm{C}$; and $0.065 \mathrm{~g}, \mathrm{mp}$ $140-141^{\circ} \mathrm{C}$. Yield, $0.415 \mathrm{~g}(52.5 \%)$. IR (KBr) $2250 \mathrm{~cm}^{-1}(\mathrm{CN})$ and $1673 \mathrm{~cm}^{-1}(\mathrm{CO}) .{ }^{1} \mathrm{H}-\mathrm{NMR}\left(\mathrm{CDCl}_{3}, 300 \mathrm{MHz}\right), 3.85 \mathrm{ppm}$, $\mathrm{s}\left(\mathrm{OCH}_{3}\right) ; 3.90 \mathrm{ppm}, \mathrm{s}\left(\mathrm{OCH}_{3}\right)$; ( $4.05 \mathrm{ppm}\left(\mathrm{CH}_{2}\right) ; 6.94 \mathrm{ppm}$, $\mathrm{d}, \mathrm{J}=8.4 \mathrm{~Hz}(\mathrm{H}-5) ; 7.54 \mathrm{ppm}, \mathrm{d}, \mathrm{J}=2 \mathrm{~Hz}(\mathrm{H}-2)$ and $7.72 \mathrm{ppm}$, $\mathrm{dd}, \mathrm{J}=8.4$ and $\mathrm{J}=2 \mathrm{~Hz}(\mathrm{H}-6)$.

Anal. calcd. for $\mathrm{C}_{11} \mathrm{H}_{11} \mathrm{NO}_{3}$ : C, 64.37; H, 5.40; N, 6.82. Found: C, 64.42; H, 5.33; N, 6.60.

EI-MS: $\mathrm{M}^{+}$205, $32 \%$; m/z 165, $100 \%\left(\mathrm{Ar}-\mathrm{CO}^{+}\right)$. MW calc. for $\mathrm{C}_{11} \mathrm{H}_{11} \mathrm{NO}_{3}, 205$. (Compound 1 ).

In an experiment with $10 \mathrm{~g}$ of $\alpha$-bromoacetoveratrone and $15 \mathrm{~g}$ of $\mathrm{KCN}$, a byproduct, $\underline{5}$, insoluble in $\mathrm{MeOH}$, could be isolated from the mother liquor: $0.92 \mathrm{~g}, 26 \%$; mp $130-160^{\circ} \mathrm{C}$. Fractional crystallizations from $\mathrm{CH}_{2} \mathrm{Cl}_{2}-\mathrm{MeOH}, \mathrm{CH}_{2} \mathrm{Cl}_{2-}$ EtOH and $\mathrm{CH}_{2} \mathrm{Cl}_{2}-\mathrm{Et}_{2} \mathrm{O}$, yielded white microcrystals, mp $165-167^{\circ} \mathrm{C}(0.22 \mathrm{~g}, 6 \%)$. IR (KBr) $2246 \mathrm{~cm}^{-1}(\mathrm{CN}), 1683$ and $1670 \mathrm{~cm}^{-1}$ (CO). ${ }^{1} \mathrm{H}-\mathrm{NMR}: 3.51 \mathrm{ppm}, \mathrm{dd}, \mathrm{J}_{\mathrm{ab}}=17.7$ and $\mathrm{J}_{\mathrm{ax}}=4.2 \mathrm{~Hz}\left(\mathrm{H}_{\mathrm{a}}, \mathrm{CH}_{2}\right) ; 3.82$ ppm, s $\left(\mathrm{OCH}_{3}\right) ; 3.84$ ppm, s $\left(\mathrm{OCH}_{3}\right) ; 3.97$ ppm, s $\left(\mathrm{OCH}_{3}\right) ; 3.99$ ppm, s $\left(\mathrm{OCH}_{3}\right) ; 4.06 \mathrm{ppm}$, $\mathrm{dd}, \mathrm{J}_{\mathrm{ab}}=17.7$ and $\mathrm{J}_{\mathrm{bx}}=9.0 \mathrm{~Hz}\left(\mathrm{H}_{\mathrm{b}}, \mathrm{CH}_{2}\right) ; 5.04 \mathrm{ppm}$, dd, $\mathrm{J}_{\mathrm{bx}}=9.0$ and $\mathrm{J}_{\mathrm{ax}}=4.2 \mathrm{~Hz}(\mathrm{CH})$. The two aromatic ABX spin systems give rise to the following signals: 6.93 and $6.98 \mathrm{ppm}, \mathrm{d}$, $\mathrm{J}=8.4 \mathrm{~Hz}$ (H-5 and H-5'); 7.50 and $7.56 \mathrm{ppm}, \mathrm{d}, \mathrm{J}=1.8$ and $2.1 \mathrm{~Hz}(\mathrm{H}-2$ and $\mathrm{H}-2$ ' $)$; 7.67 and $7.80 \mathrm{ppm}, \mathrm{dd}, \mathrm{J}=8.4$ and 2.1 $\mathrm{Hz}, \mathrm{J}=8.7$ and $2.1 \mathrm{~Hz}$ (H-6 and H-6').

Anal. calcd. for $\mathrm{C}_{21} \mathrm{H}_{21} \mathrm{NO}_{6}$ : C, 65.77; $\mathrm{H}, 5.52 ; \mathrm{N}, 3.65$. Found: C, 65.90; H, 5.30; N, 3.41.

EI-MS: $\mathrm{M}^{++} 383,36 \% ; \mathrm{m} / \mathrm{z} 365,12 \%\left(\mathrm{M}^{+}-\mathrm{H}_{2} \mathrm{O}\right) ; \mathrm{m} / \mathrm{z}$ $165,100 \%\left(\mathrm{Ar}-\mathrm{CO}^{+}\right) ; \mathrm{m} / \mathrm{z} 137,12 \%\left(\mathrm{Ar}^{+}\right)$. MW calc. for $\mathrm{C}_{21} \mathrm{H}_{21} \mathrm{NO}_{6}, 383$. (Compound $\underline{5}$ ).

This compound has been synthesized[12], not isolated as a byproduct. It was reported with the inadequate name 1-cyano-1,2-diveratroylethane and $\mathrm{mp} 148-149^{\circ}$, instead of $165-167^{\circ}$ of our product. 


\section{Conclusions}

The basic structure of an unexpected reaction byproduct was established. However, some organic compounds posses a secondary structure, which can be due to hydrogen bonding. This type of interactions alter the spectral data in comparison to the data arising from less complex (normal) compounds. Based on modern spectral analysis, we have elucidated the secondary structure of 2,3-bis-(3,4-dimethoxybenzoyl)propionitrile, demonstrating the existence of two hydrogen bonds that form two secondary five-membered rings.

\section{REFERENCES}

[1] Francisco Sanchez-Viesca, Martha Berros, "1H NMR evidence of C-H---O, C-H---N and C-H---Cl hydrogen bonds in new thiazole derivatives", Elsevier, Heterocycles, vol. 57, no. 10, pp. 1869-1879, 2002.

[2] Francisco Sanchez-Viesca, Martha Berros, M. Reina Gomez, "Intramolecular weak hydrogen bonds in substituted 4-arylthiazoles", Freund Publishing House, Heterocyclic Communications, vol. 9, no.2, pp. 165-170, 2003.

[3] Francisco Sanchez-Viesca, Martha Berros, "Intramolecular hydrogen bonding in the nitrobenzopyridines", Freund Publishing House, Heterocyclic Communications, vol. 13, no. 4, pp. $215-218,2007$.

[4] Francisco Sanchez-Viesca, Martha Berros, "Dimethoxy- and trimethoxyphenyl aminoisoxazoles with structural isomerism. Synthesis and spectroscopy", Universidad Nacional Autonoma de Mexico, TIP: Revista Especializada en Ciencias Quimico-Biologicas, vol. 7, no. 1, pp. 10-17, 2004.
[5] Holger Erdtman, Bengt Leopold, "Aromatic keto- and hydroxy- polyethers as lignin models. II", Munksgaard Intrnational Publishers, Acta Chemica Scandinavica, vol. 3, pp. 1358-1374, 1949.

[6] L. Carrol King, G. Kenneth Ostrum, "Selective bromination with copper (II) bromide", American Chemical Society, Journal of Organic Chemistry, vol. 29, no. 12, pp. 3459-3461, 1964.

[7] Francisco Sanchez-Viesca, M. Reina Gomez, "2,4,5- Trimethoxyphenyl ketones. Synthesis and spectroscopy of new compounds", Patronato de Ciencia, Ciencia-Mexico, vol. 27, no. 6, pp. 185-189, 1972.

[8] Francisco Sanchez-Viesca, M. Reina Gomez, "Polymethoxyaryl and polymethoxydiaryl heterocycles prepared by Houben-Hoesch reactions", Laboratorios Mixim, Revista Latinoamericana de Quimica, vol. 10, no. 4, pp. 162-166, 1979.

[9] Ursula Weber, Herbert Thiele, NMR Spectroscopy: Modern spectral analysis, Wiley-VCH, Weinheim, Germany, 1998. p. 203.

[10] Roy Henderson Bible, Jr., Interpretation of NMR spectra, Plenum, New York, USA, 1965. pp. 35-36.

[11] Erno Pretsch, Philippe Bühlmann, Christian Affolter, Structure determination of organic compounds, Tables of spectral data, 3th ed., Springer, Berlin, Germany, 2000. p. 166.

[12] Saburo Tamura, Saburo Suzuki, Kazubiko Ocuma, Hide Okubo, "Inhibition of the autoxidation of fats and oils. XII. Supplement to the syntheses of some $\omega, \omega$ '-bis(3,4- dihydroxyphenyl)alkanes", Agricultural Chemical Society of Japan, Nippon Nogei-kagaku Kaishi, vol. 28, pp. 490-494, 1954; Chemical Abtracts, vol. 51, p. 14,618d, 1957. 